\title{
Pedagogy of Interiority as a Tool for Social-Emotional Education in the New Model of Public Education in Mexico: Scope and Limitations
}

\author{
Hilda Patiño Domínguez, PhD \\ Iberoamericana University, México
}

Doi: 10.19044/esj.2018.c5p16 ～URL:http://dx.doi.org/10.19044/esj.2018.c5p16

\begin{abstract}
Based on the essential characteristics of the New Model for Public Education in Mexico, which will begin to operate in August 2018 throughout the country, this paper focuses on the introduction of social-emotional education in the curriculum of primary and secondary levels. It is, however, regarded as one of the most outstanding changes established in the Model. It offers a brief analysis of the theoretical-pedagogical principles of socialemotional education, as well as the main challenges that it would have to face to be implemented. The objective of this paper is to analyze the challenges posed by the implementation of socio-emotional education in the basic education curriculum in Mexico, specifically the one that implies the adoption of an adequate pedagogical approach. For this purpose, a comparative analysis was undertaken between the educational proposal of the model and the proposal of the Pedagogy of Interiority. This was carried out through the revision of the main categories of both approaches to detect their compatibility and complementarity. The analysis concludes that the Pedagogy of Interiority can contribute to a better appropriation and implementation of the proposal of Socio-Emotional Education in the Mexican Model.
\end{abstract}

Keywords: Social-emotional education, educational reforms, the pedagogy of interiority

\section{Introduction}

Mexico have faced severe problems in its attempt to provide quality public education to its citizens. In the 2016-2017 school year, almost 26 million students attained the primary and secondary levels, reaching $96.3 \%$ coverage (NSIS, 2017). Although school drop-out rate is not a problem at these levels, the results obtained in regards to learning are abysmal. According to 2015 PISA results, Mexico's performance is below average in 
science with 416 points while across the OECD with the standard of 496; in reading with 423 points, which is below the OECD average of 493; and in mathematics, Mexico ranked the lowest score of all 34 OECD countries with 408 points, while the average is 490 . In these three areas, less than $1 \%$ of students in Mexico achieved levels of proficiency (levels 5 and 6) (OECD, 2015).

Additionally, as Canedo $(2016,1)$ points out: "Government spending on schooling has not translated into gains in the quality of education. While Mexico spends 22 percent of public non-capital spending on education, the highest share in the OECD, spending per student is only one-third of the OECD average and the second lowest percentage among OECD and partner countries. Mexico devotes nearly 94 percent of its education budget towards teachers' salaries and staff compensation."

Although there are many problems due to poverty and poor distribution of wealth in the country, most of the responsibility for the low performance of the students is attributed to the poor quality of teachers. The government has little control in hiring or dismissing them because they receive protection from the National Union of Education Workers (SNTE), probably the most powerful union in Latin America.

During Enrique Peña Nieto 's government, and after a change in the leadership of the SNTE, long-term educational reform was established as of December 2012. However, the first part of this reform was focused on the evaluation of teachers' performance. This is with the aim of training, promoting, and eventually removing them from their posts if they were not able to accredit their competence. To this end, the government created the National Institute for Educational Evaluation (INEE). Teacher riots and protests were common, and there were much criticism and unconformity of how the educational reform had been implemented. This also alleges that it was not an educational reform, but a labor one since there was no proposal for pedagogical transformation of the curriculum.

However, the document of the reform itself established that a new educational model should be created as part of it. After several revisions and consultations, this model was promulgated in the Official Gazette of the Federation on June 28, 2017. Thus, it will start operating in all schools in August 2018.

The New Educational Model declares itself humanist and advocates the integral formation of people. Among the most relevant developments are the introduction of a socio-emotional development area in the primary and secondary curriculum. It also entails an area of curricular autonomy that will allow schools to decide on specific curricular contents according to their needs and contexts. 
The objective of this paper is to analyze the challenges posed by the implementation of socio-emotional education in the basic education curriculum in Mexico, specifically the one that implies the adoption of an adequate pedagogical approach. This is because the model has specific deficiencies in this sense. For this purpose, a comparative analysis was undertaken between the educational proposal of the model and the proposal of the Pedagogy of Interiority. This was carried out through the revision of the main categories of both of them to detect their compatibility and complementarity. The analysis concludes that the Pedagogy of Interiority can be an approach that contributes to a better appropriation and implementation of the proposal of Socio-Emotional Education in the Mexican model.

\section{The Importance of Educating Emotions}

Emotions play a significant role in learning. Also, self-regulation is vital for a person to perform productively and successfully in daily coexistence with their peers in the workplace, family, and the society in general. It is essential to learn how to manage their emotions to self-produce states of tranquility, peace, and inner security. Therefore, it will allow them to better face the challenges and difficulties that life presents.

In this sense, socio-emotional education seeks to establish preventive measures to solve emotional problems that affect society in general, among which we can mention the following (INEGI: 2015):

- Depression: According to INEGI data in Mexico, in 2013, 5,909 suicides were recorded. This, however, represents $1 \%$ of registered deaths; placing itself as the fourteenth cause of death and presenting a rate of about five per 100 thousand. $40.8 \%$ of suicides occur in young people between 15 and 29 years old. Among them, the rate reaches 7.5 suicides per 100 thousand young people. Of the total deaths that occurred in 2013,81.7\% were completed by men and $18.2 \%$ by women.

- Violence in the School: Mexico is the first place of bullying in countries that make up the Organization for Economic Cooperation and Development (OECD). Out of more than 26 million students at the basic level, between 60 and $70 \%$ has suffered violence. Also, it has affected 18, 781,875 primary and secondary students, both public and private, according to an OECD study. Even when accurate records are lacking, the absence of policies to prevent violence and bullying has resulted in low academic performance, desertion, as well as an increase in suicide among young people of secondary and upper secondary school age (SPSE, 2015).

International evidence shows that it is fundamental to support and invest in socio-emotional learning and the integral development of adolescents, considering that they are at a critical age when they begin to make crucial decisions in their lives. In the case of Mexico, the National 
Survey of Exclusion, Intolerance and Violence 2013 (ENEIVEMS) applied at the high school level showed that $56 \%$ of students feel sad, $44 \%$ feel alone, and $26 \%$ feel that their life has been a failure. In the case of the PLANEA test, applied in 2015 to junior high school students, it was observed that only $15 \%$ of the students surveyed said they had a high level of perseverance, less than 2 out of 10 (18.4\%) indicated that With decisionmaking skills, only 1 in 7 knew how to handle stress adequately, and only 2 out of $100(1.6 \%)$ said they had a high level of empathy.

Other figures that are relevant for Mexico are those referring to teenage pregnancy, which is associated with a loss of 1 to 1.2 years of schooling in the long term for women. This can also be seen for the case of the high dropout rate at the level of upper medium. At this level, only $45.6 \%$ of the students who initially entered this level were able to conclude it.

The data presented here gives an account of a context in which risk behavior, violence, and school desertion can truncate the educational trajectory of students, and thereby limit their life choices. In this line, OECD (2015) has recently stated that an adequate acquisition of cognitive and socio-emotional skills were fundamental to individual well-being.

\section{Socio-Emotional Education (SEE) in the New Educational Model in Mexico}

Etymologically, the term "emotion" comes from the Latin word "emotĭo," meaning "movement or impulse" and "that which moves towards." Psychologists defined "emotions" as psychophysiological reactions that occurs in a neutral organism as adaptive responses to the environment. Hence, they are a kind of "trigger" of behaviors before specific stimuli.

Emotions can be experienced in a pleasurable way, causing states of tranquility and joy, and unpleasantly, causing states of uneasiness or pain. We call the former "positive emotions" or non-afflictive emotions, and the latter, "negative emotions" or afflictive emotions (Bisquerra, 2015).

Neuroscientific studies generally speak of five basic emotions, which are those that are connected to the limbic system, the oldest and inner part of our brain: joy, sadness, anger, fear, and disgust. These emotions arise spontaneously and are associated with survival mechanisms. They have little relation to the neocortical processes so that the subject suffers them and cannot do much to control their appearance. This is despite the fact that he can learn to manage the way through which he externalizes them behaviorally.

In addition to the primary emotions, there are much more complex emotions, called secondary emotions or feelings, which are formed by a combination of the basic ones and by the influence of the sociocultural environment in which a person develops. They are more lasting moods than 
the pure emotional experience and a trace of the characteristics of the personality. Examples of this type of secondary emotions are jealousy, envy, the desire for revenge, the feeling of persecution, resentment, and other precedents, which we might call negative. On the positive side, examples include solidarity, surrender, care, respect, aesthetic experience, altruism, love, and all those that lead to fuller and happier states of life.

Since people learn to respond emotionally within their specific social context and culture, the term "social-emotional education" has been preferred to indicate that emotions and their manifestation always involve a social component. Thus, this also means that the handling of emotions can be taught and learned, and in fact, various pedagogical proposals have been developed with this aim. The SEE provides internal resources to address the challenges that may arise throughout life (Reimers \& Chung, 2016). In addition, it contributes to the development of personal talents and active participation in building a more inclusive and supportive world.

The SEE Program of the New Educational Model seeks to establish preventive measures to help solve problems such as violence and destruction of the social fabric, bullying (SIPSE, 2015), depression, lack of motivation, eating disorders or early pregnancies, among others. SEE is defined as: "a learning process through which children and adolescents develop and integrate into their lives the concepts, attitudes, and skills that allow them to understand and manage their own emotions, build their identity, show empathy for others, collaborate, establish positive relationships and make responsible decisions." (SEP, 2017, 7)

The Socio-Emotional Education contributes to the formation of responsible, free, inclusive and supportive citizens. Therefore, these citizens are capable of overcoming individualism and building a community environment by promoting one's well-being, that of others, and the situation. It seeks, through a process of lifelong learning, the acquisition and construction of personal skills for socialization. This uses integrated and enhanced cognitive development to generate a comprehensive education. Its objective states that students should put into practice actions and attitudes aimed at creating a sense of well-being, with themselves and for others, through activities and routines associated with school activities. In doing so, they will learn to deal satisfactorily with their impulsive or afflictive emotional states. Also, they would learn to manage to make emotional life and interpersonal relationships a trigger for motivation, learning, and the completion of substantive and constructive goals in life. In this sense, the school should be the ideal space for the construction of relationships, the solution of conflicts, and the development of tolerance and respect, which are essential aspects for a healthy coexistence and the creation of a peaceful and democratic society. 
The socio-emotional education is the axis of the integral formation because it allows the students to consolidate a healthy sense of identity and direction that helps them to make decisions to act freely. However, it takes into account the repercussion of their actions and decisions on their peers, next or far. For this reason, it pays to the formation of the sense of agency and the citizenship that can work in solidarity for the causes of the common good.

SEE is based on a model that articulates five dimensions: 1) selfknowledge, 2) self-regulation, 3) autonomy, 4) empathy, and 5) collaboration.

These five dimensions are briefly described below:

1) Self-knowledge: This ability is essential to a person's emotional life because it is based on other skills such as self-esteem, self-regulation, selfefficacy, and moral autonomy. It involves developing attention to one's own cognitive and emotional processes, the identification of emotions, and their proper expression. The purpose of self-knowledge is to be able to accept oneself, and to strengthen the sense of identity through taking and valuing oneself.

2) Self-regulation is the ability to modulate one's thoughts, emotions, feelings, and behaviors; it involves controlling impulses, tolerating frustration, persevering in the achievement of objectives, postponing the need for immediate rewards, managing the intensity and duration of emotional states, and even voluntarily arising constructive emotions. Proper selfregulation of one's own emotions helps people to be more reflective and tolerant, and it also increase their capacity for listening and dialogue. This, thus, contributes to creating an emotionally healthy climate in the environments in which they operate, favoring inclusion, collaboration, and the constructive solution of conflicts. Therefore, working with capacities to deal with our emotional states is essential to strengthen self-regulation.

3) Autonomy has various manifestations in the intellectual, emotional, and moral spheres. In the mental aspect, it means the ability to think for oneself: in terms of emotions, to regulate moods adequately; and in terms of morals, to make decisions about what is right or just considering the consequences that these decisions have on those around us. To achieve autonomy, the person needs to develop skills for self-knowledge and to possess a sense of self-efficacy and agency, that is, confidence in one's abilities to achieve the proposed objectives as well as to overcome obstacles that arise.

4) Empathy is fundamental in human communication because it involves the ability to perceive, identify, and understand behavioral and attitudinal elements that the other communicates, whether through verbal, corporal, and gestural language. Thanks to our empathic capacity as we can give fair 
treatment to others, provide support, take care of nature, and generate wellbeing around us. Hence, empathy is an essential element to create healthy interpersonal relationships and constitutes the basis of solidarity, compassion, and human reciprocity (Zahavi, 2001).

5) Collaboration is defined as the set of skills that a person develops to establish harmonious relationships with others that lead to the achievement of group goals. It implies the construction of the sense of "we," which goes beyond the perception of merely individual needs so that the individual becomes aware of being a member of a community and seeks in their actions the good of it. Appropriating this skill requires being aware that in the group in which you interact, you can build positive relationships and build the habit of mutual help and set common goals.

For each of these five dimensions, the model establishes five vital social-emotional skills that can be seen in the following scheme:

\begin{tabular}{|c|c|}
\hline Dimension & Associated Skills \\
\hline 1. Self-knowledge & 1.1. Attention \\
& 1.2. Awareness of one's emotions \\
1.3. Self-esteem \\
1.4 Appreciation and gratitude \\
1.5. Wellness
\end{tabular}


Emotional education has two strong pedagogical components: teacher modeling and learning experiences designed to develop students' emotional world which allows reflection. However, this is to enable them identify their own emotions and its proper management, gives more harmonious coexistence, and makes personal life more fulfilled and happy. Based on this purpose, a progressive order of achievement levels has been established for each social-emotional skill, which goes from the first year of primary to the third year of secondary education, and the experts designed diverse classroom, activities for each skill according to this progression. The teachers will use these activities during the time they will dedicate to this program: 30 minutes a week in primary, and 50 minutes in Secondary. Also, the idea is to ensure that SEE is a cross-curriculum element so that in all subjects as well as in all extracurricular activities, one can foster these socialemotional skills.

\section{The Implementation of Socio-emotional Education: Challenges and Opportunities}

There are at least three key factors that imply serious challenges in the ESE implementation process: 1) parental support, 2) teacher training, and 3 ) the development of an adequate pedagogy that includes the assessment of the socio-emotional education. The present work focuses on this last challenge, but before tackling it, we will briefly review the first two challenges.

Regarding parental support, it is an element that is crucial to avoid conflicting messages that may be counterproductive. Socio-emotional education needs to propose strategies for parents to know, assume, and join the efforts of emotional education that will not be only for the good of the children but for the whole family. In the new educational model, there is a much closer link between teachers and parents through the strengthening of schools for parents and the presence of parents in school councils (Councils of Social Participation). Millions of children in Mexico live in conditions of poverty and marginalization, in insecure contexts, and they face problems of violence both outside and inside families. Social-emotional education can help heal emotional wounds through programs specially directed to parents and guardians. The school directors are a key element to promote the approach of the parents to the school, but there remains much to define about this problem.

Regarding teacher training, this is an aspect of which the school has greater control, but it requires the support that the government can provide to fund training workshops aimed not only at the knowledge of the program but the emotional development of teachers. There are several important reasons to train teachers in this regard. The following are the most important ones: 
- First, since a curricular space for Social-Emotional Education was not previously conceived in the plans and programs of study, it is imperative that teachers should know and take ownership of the proposal through their training programs.

- Secondly, the most important way of socio-emotional education is modeling. In this area, as in no other, what works best for learning is the example of the teacher's actions, and not so many theoretical conceptualizations about emotions, their classifications, and ways of controlling them. Although conceptual knowledge is undoubtedly useful, what is genuinely crucial is the deployment of attitudes, behaviors, and habits that induce favorable emotional states that can be emulated by students. In the field of social-emotional education, the teacher must be fully aware that he/she is a model of attitudes and behaviors.

To become models, teachers must also develop their ability to be in contact with their own emotions, identifying, expressing and modulating them. They need to be aware of the way in which their interpretations of the facts and the circumstances influence their mood. As a result, they can learn to respond with attitudes and behaviors that enhance constructive interpersonal relationships and a sense of well-being.

Teacher training is perhaps the most significant challenge that socioemotional education has. Hence, it requires designing strategies that include training programs in various modalities: online, blended, face-to-face, as well as a variety of materials. The Mexican Ministry of Education has to establish essential alliances with universities throughout the country, where specialists in socio-emotional education are located. Also, they should implement projects that allow socio-emotional education to be brought to nearly $1,400,000$ basic education teachers, which seems an almost impossible task to achieve. On the other hand, from an optimistic perspective, it can be affirmed that in reality, socio-emotional education is something that most teachers already practice in the classroom, although not explicitly or with clear pedagogical rationality.

\section{Pedagogy of Interiority as a Tool for Socio-emotional Education in the New Educational Model of Public Education in Mexico}

As stated in the introduction, this paper focuses on analyzing the challenges posed by the implementation of socio-emotional education in the basic education curriculum in Mexico. This is specifically for the one that implies adopting an adequate pedagogical approach, since the model presents specific deficiencies in this regard. For this purpose, a comparative analysis was undertaken between the educational proposal of the model and the proposal of the pedagogy of interiority. This is done through the revision of 
the main categories of both them to detect their compatibility and complementarity.

The challenge of implementing the SEE in which we want to emphasize in this text refers especially to developing an appropriate pedagogy and teaching materials based on that pedagogy. In the market, many self-help materials are not always supported by a scientific approach and, besides being lacking in seriousness, they can be used to manipulate people. The Secretariat of Public Education, with the help of specialists, has developed both a didactic approach and materials in the form of "record cards," which contain activities for promoting socio-emotional development. The educational approach adopted is based on experience, through dynamics and games, to encourage reflexive processes of introspection. In general, it does not deepen this approach.

For this reason, this paper proposes to analyze in greater depth the pedagogy that should support social-emotional education. In this sense, we consider that the most promising approach comes from the so-called "Pedagogy of Interiority," which has been developed by a group of academics from the University of Barcelona. Thus, this university is one of the first institutions of higher education in the Hispanic world who offers socialemotional education. The objective of this pedagogical proposal is to get the person to connect with their interiority to favor their inner growth but not to stay in an intimate setting, but to be able to interact with others constructively and proactively. To develop interiority would be in this sense "to be more oneself, to know how to recognize what one is and how and where it is, to widen the inner world and ultimately to inhabit more and better in oneself" (Galve \& Lullá, 2013, 43).

This pedagogical proposal holds that the knowledge and development of interiority can be the object of learning: it is a pedagogy that helps us to look inwards and from there look out wards. Deepening our inner dimension implies deliberate pedagogical efforts to promote awareness, experience and the elaboration of the experience. Promote the processes of sustained and focused attention, silence, meditation and other forms of introspective work, dialogue through open questions, attitudes of listening, acceptance and inclusion, all those that favor the broadening of consciousness, that stimulate interest and creativity and metacognitive processes, to name a few are the elements of this pedagogical style.

The individual's interior is a dynamic. It has a fluctuating reality in which wishes, emotions, feelings, memories, beliefs, and convictions are mixed. Pedagogy of Interiority assumes the need to make a journey within ourselves, and like any trip, implies an exploration of our limits: "We discovered how far we could endure. The limit tells us who we are, regulates our identity, but it is also the frontier that indicates the meaning of our march" 
(Otón Catalán, 2013, 62). Hence, the great poet "Rilke" has affirmed that the actual journey is towards the interior. As one can guess, the categories of travel and exploration are essential for this pedagogical approach that focuses on socio-emotional education from a personal growth perspective. Become more owners of ourselves, live more fully, know how to create emotional states of peace and joy, achieve inner well-being and engage in similar constructive relationships are the great purposes from which socio-emotional education makes sense, and the pedagogy of interiority becomes an indispensable ally of the social-emotional education.

\section{Methodology of Comparative Analysis between Pedagogy of Interiority and the Model of Socio-emotional Education}

The present work proposes to analyze the possible contribution of Pedagogy of Interiority in the implementation of socio-emotional education in the Mexican model. As a result, it is necessary to contrast the objectives of socio-emotional education against the pedagogy of interiority. The following table presents the result of this analysis through the categories of analysis that helped to contrast the objectives of socio-emotional education against Pedagogy of interiority. It was carried out through the review of the sources consulted.

\begin{tabular}{|c|c|c|c|}
\hline & $\begin{array}{l}\text { Socio-emotional Education } \\
\text { (ESE) of the New } \\
\text { Educational Model }\end{array}$ & $\begin{array}{l}\text { Pedagogy of the } \\
\text { Interiority } \\
\text { (PI) }\end{array}$ & $\begin{array}{l}\text { Similarities and } \\
\text { Differences }\end{array}$ \\
\hline Objectives & $\begin{array}{l}\text { Students will put into } \\
\text { practice actions and } \\
\text { attitudes aimed at } \\
\text { generating a sense of well- } \\
\text { being, with themselves and } \\
\text { for others, through } \\
\text { activities and routines } \\
\text { associated with school } \\
\text { activities, so that they can: } \\
\text { - understand and learn to } \\
\text { cope satisfactorily with } \\
\text { impulsive or afflictive } \\
\text { emotional states, and } \\
\text { - manage to make } \\
\text { emotional life and } \\
\text { interpersonal relationships } \\
\text { a trigger for motivation, } \\
\text { learning and the } \\
\text { completion of substantive } \\
\text { and constructive goals in } \\
\text { life }\end{array}$ & $\begin{array}{l}\text { Encourage internal } \\
\text { growth of people, to } \\
\text { interact with others } \\
\text { productively and } \\
\text { proactively. } \\
\text { To develop the } \\
\text { interiority would be } \\
\text { in this sense "to be } \\
\text { more oneself, to } \\
\text { know how to } \\
\text { recognize what one } \\
\text { is and how and } \\
\text { where it is, to } \\
\text { widen the inner } \\
\text { world and } \\
\text { ultimately to inhabit } \\
\text { more and better in } \\
\text { oneself" }\end{array}$ & $\begin{array}{l}\text { Both approaches } \\
\text { coincide with the } \\
\text { main objective of } \\
\text { achieving the inner } \\
\text { well-being of people } \\
\text { to achieve a better } \\
\text { coexistence }\end{array}$ \\
\hline Contents & $\begin{array}{l}\text { The five socio-emotional } \\
\text { dimensions and their }\end{array}$ & $\begin{array}{l}\text { It emphasizes the } \\
\text { following: }\end{array}$ & $\begin{array}{c}\text { PI can be an } \\
\text { important aid in the }\end{array}$ \\
\hline
\end{tabular}




\begin{tabular}{|c|c|c|c|}
\hline & $\begin{array}{c}\text { associated abilities: } \\
\text { - Self-knowledge } \\
\text { • Self-regulation } \\
\text { • Autonomy } \\
\text { • Empathy } \\
\text { • Collaboration } \\
\text { We must work better for } \\
\text { the dimensions of } \\
\text { autonomy and empathy, } \\
\text { which are unclear in the } \\
\text { model }\end{array}$ & $\begin{array}{l}\text { - Self-knowledge } \\
\text { •Self-regulation } \\
\text { - Autonomy } \\
\text { These dimensions } \\
\text { have the objective } \\
\text { that the person } \\
\text { becomes "more } \\
\text { owner of herself." }\end{array}$ & $\begin{array}{l}\text { development of the } \\
\text { first three emotional } \\
\text { dimensions }\end{array}$ \\
\hline $\begin{array}{l}\text { Pedagogical } \\
\text { methodology }\end{array}$ & $\begin{array}{c}\text { Active learning methods } \\
\text { through dynamics and } \\
\text { games } \\
\text { Experience- Reflection- } \\
\text { Interiorization } \\
\text { Playful approaches: } \\
\text { learning based on the } \\
\text { game }\end{array}$ & $\begin{array}{c}\text { Introspective } \\
\text { methods: } \\
\text { Discernment } \\
\text { A trip, exploration } \\
\text { inside } \\
\text { Notion of limit }\end{array}$ & $\begin{array}{l}\text { The methods are } \\
\text { compatible and can } \\
\text { enrich each other. } \\
\text { ESE emphasizes } \\
\text { play and experience. } \\
\text { PI emphasizes } \\
\text { experience and } \\
\text { introspection. PI has } \\
\text { worked in greater } \\
\text { depth on these } \\
\text { methodologies }\end{array}$ \\
\hline Assessment & $\begin{array}{l}\text { Formative assessment that } \\
\text { allows the progressive } \\
\text { improvement of the socio- } \\
\text { emotional skills } \\
\text { Emphasis on } \\
\text { metacognition }\end{array}$ & $\begin{array}{l}\text { The assessment } \\
\text { process is personal } \\
\text { and is carried out } \\
\text { according to the } \\
\text { criterion of inner } \\
\text { well-being } \\
\text { Focus on self- } \\
\text { evaluation }\end{array}$ & $\begin{array}{l}\text { There is a } \\
\text { fundamental } \\
\text { coincidence in the } \\
\text { approaches, beyond } \\
\text { the language } \\
\text { differences }\end{array}$ \\
\hline
\end{tabular}

As can be seen, both proposals coincide with the general objective of achieving the subjective well-being of people that have an impact on a better interpersonal coexistence. In terms of content, the Mexican model emphasizes five dimensions: three intrapersonal (self-knowledge, self-regulation, and autonomy) and two interpersonal (empathy and collaboration). In this sense, it offers a more complete proposal than the Pedagogy of Interiority, which focuses on the development of intrapersonal dimensions. Therefore, this was done so as to play a significant role in their development. Besides, the Pedagogy of Interiority can contribute to strengthening the idea of autonomy through the process of discernment that takes into account the analysis of the emotions experienced by the person.

There is a possibility of an essential contribution of Pedagogy of Interiority for the Mexican model which is in the pedagogical methodology. The Mexican model speaks of strategies based on experience and the game to encourage the reflection of the person, but does not deepen in this proposal nor offers more elaborate sustenance. The Pedagogy of Interiority, 
meanwhile, has devoted itself to increasing methodologies that favor introspection and reasoned decision making through discernment exercises that comes from philosophical traditions, such as the Socratic-Platonic and the Aristotelian, or the Jesuit educational tradition. The Mexican model can benefit a lot from the knowledge of these methodologies.

Regarding the last category, it is necessary to point out that evaluating emotional development is quite complicated due to the critical burden of subjectivity that it implies (in fact, most of the instruments of evaluation of socio-emotional education are self-perception surveys) as well as the ethical dilemmas that may lead to the use of this type of assessments. From the educational point of view, the best approach is that of formative evaluation, which does not imply establishing qualifications and whose only intention is to offer the person possibilities of self-improvement. In this sense, what the Secretariat of Public Education proposes is very similar to what the Pedagogy of Interiority approach suggests. This is because both coincide in the idea that, in the education of emotions, the vital thing is not to acquire a note at the end of the course, but to promote reflexive processes that allows the improvement of social-emotional skills.

Pedagogy of Interiority focuses on inner well-being and emphasizes an evaluation that promotes greater self-knowledge, better emotional selfregulation, greater autonomy and more responsible decision-making. The Mexican model, for its part, coincides with the preceding but also emphasizes the capabilities of social interaction, empathy, and collaboration. In the emotional itinerary, there are always ups and downs, afflictive circumstances that put to the test what an individual has achieved, and lead him to setbacks that can make him feel that the road traveled was useless. However, from the formative evaluation approach, these setbacks are nothing more than new opportunities to explore the internal landscapes and learn more and grow more. It is from this positive inner growth that the foundations of an intensely lived ethic can be laid.

\section{Conclusion}

The analysis made indicates that the main advantages offered by Pedagogy of Interiority for the Mexican model of social-emotional education refers to the theoretical and methodological support that this pedagogy provides since it reflects the humanist traditions that promote the processes of introspection. These are particularly important for developing intrapersonal dimensions, among which autonomy stands out, which is the dimension that can be strengthened with the PI approach.

It is important to consider that working the emotions requires a pedagogical proposal based on humanistic philosophical anthropology that recognizes the person as a relational being, endowed with intelligence, will, 
the capacity of free will, and with an inalienable dignity. Working with emotions involves entering the human universe of interiority, what makes an individual unique and different in the world. In this sense, emotions arise from external stimuli and internal resources. For instance, memory and imagination can evocate emotional states with no anchorage to the outside world.

Now, the fundamental postulate of these authors is that it is possible to learn to know and develop interiority and that education can contribute to the development of interiority. If the social-emotional education proposed by the New Educational Model in Mexico wants to be successful, it is going to be necessary to focus the school towards the work of interiority seriously. Concentration, the development of concentrated attention, silence, the exploration of one's moods, the identification of the reasons that lead us to make a decision, are only examples that imply the dimension of interiority in pedagogical work of emotions. Therefore, promoting this look will be the challenge for the school in the years to come.

\section{References:}

1. Bisquerra, R. (2013), (coord). Educación emocional. Propuestas para educadores y familias. Sevilla: Desclée de Boruwer.

2. Canedo, A. (2016). "Mexico 's Educational Reform, What went wrong?" in Georgetown Public Policy Review, March $10^{\text {th }}$, Consulted in http://gppreview.com/2016/03/10/mexicos-educationreform-what-went-wrong/, 2016.CIDE, Centro de Investigación y Docencia Económica en: https://www.cideconsultamodedu2016.info/portafolio

3. Galve, R. \& Lluís Ylla (2013), ¿De qué hablamos cuando hablamos de interioridad en la escuela?" en López González, L. (Maestros del corazón. Hacia una pedagogía de la interioridad. Wolters Kluwer España, Madrid.

4. NSIS (National Statistical Information System) (2017). Sistema Nacional de Información Estadística Consulted in http://www.snie.sep.gob.mx/indicadores_x_entidad_federativa.html

5. OECD (2015). Skills for Social Progress: The Power of Social and Emotional Skills, OECD Skills Studies, OECD Publishing. En http://dx.doi.org/10.1787/9789264226159-

6. Otón Catalán, J. (2013). "La interioridad. El órgano del sentido" en López González, L. Maestros del corazón. Hacia una pedagogía de la interioridad. Wolters Kluwer, Madrid.

7. Reimers, F. \& Chung, C. (2016). Enseñanza y Aprendizaje en el S. XXI, Metas, políticas educativas y currículo en seis países, México: Fondo de Cultura Económica. 
8. SEP (2017). Nuevo Modelo Educativo , Diario Oficial de la Federación del jueves 28 de junio de 2017. Disponible en http://dof.gob.mx/nota_detalle.php?codigo $=5488475 \&$ fecha $=29 / 06 / 2$ 017

9. SIPSE (2015) Consulted in: http://sipse.com/mexico/mexico-es-elprimer-lugar-de-bullying-a-escala-internacional-92405.html

10. Zahavi, D. (2001). "Beyond Empathy. Phenomenological approaches to intersubjectivity". Journal of Consciousness Studies, 8 (5-7): 151167. 